\title{
FAKTOR-FAKTIR YANG MEMPENGARUHI MOTIVASI SISWA SEKOLAH DASAR DALAM MENGIKUTI AKTIVITAS PRAMUKA PENGGALANG
}

\author{
Yuliana ${ }^{1}$, M. Jaya Adi Putra ${ }^{1 *}$, Zariul Antosa ${ }^{1}$ \\ ${ }^{1}$ Program Studi Pendidikan Guru Sekolah Dasar, \\ Fakultas Keguruan dan IImu Pendidikan, Universitas Riau, Pekanbaru, Indonesia \\ “汭a.adiputra@lecturer.unri.ac.id \\ Received: July $06^{\text {st }}, 2020$ \\ Revised: August $18^{\text {th }}, 2020$ \\ Accepted: August $20^{\text {th }}, 2020$
}

\begin{abstract}
This article was written based on qualitative research on students' motivation in participating in Boy Scout exercises. This article aims to describe the motivation of students in one integrated Islamic elementary school in Pekanbaru to take part in a scout-raising(penggalang) exercise. The sample in this study were 17 students raising, consisting of 9 men and 8 women. Data was collected using direct interviews with students and documentation in the form of program documents, reports and photos of activities. Held in the even semester term 2019/2020. From the results of data processing it was found that in following the Scouting activities students were influenced by several intrinsic and extrinsic factors. Intrinsic factors are first the need to be accepted and respected, secondly the hope to develop abilities, and thirdly the interests associated with socialization. Next extrinsic factor is the first family, because of the family background of a member of the scout, the second environment, the environment of friendship students become one of the students' encouragement to participate in scout activities, Thirdly the rewards, these rewards are also a bit of one of the reasons children participate in scouting activities, because of the award given by the school to students who excel in scouting activities, triggers the emergence of student motivation. With these results, it is hoped that advanced scout activities will need to consider these three factors.
\end{abstract}

Keyword: excersise; motivation; scouting.

\section{PENDAHULUAN}

Pendidikan merupakan suatu usaha untuk mengembangkan kepribadian individu dan potensi yang dimilikinya (bakat, minat dan kemampuan). Untuk mencapai semua tujuan pendidikan dan meningkatkan mutu pendidikan, maka disusunlah suatu kurikulum sebagai pedoman dalam kegiatan pembelajaran. Kurikulum yang sedang berkembang saat ini adalah Kurikulum 2013. Kurikulum 2013 memiliki empat aspek penilaian, yaitu aspek pengetahuan, aspek keterampilan, aspek sikap dan perilaku. Di dalam kurikulum 2013 juga mewajibkan 
adanya ekstrakurikuler. Kegiatan ekstrakurikuler merupakan kegiatan yang dapat menemukan dan mengembangkan potensi minat dan bakat peserta didik, serta memberikan manfaat besar dalam mengembangkan kemampuan berkomunikasi yang nantinya akan berpengaruh pada kehidupan sosial peserta didik. Salah satu kegiatan ekstrakurikuler yang wajib diikuti siswa adalah kegiatan pramuka.

Gerakan pramuka Indonesia adalah nama organisasi pendidikan nonformal yang menyelenggarakan pendidikan kepanduan yang dilaksanakan di Indonesia. Kegiatan pramuka adalah proses pendidikan diluar pembelajaran dalam bentuk kegiatan menarik di alam terbuka yang menyenangkan sebagai pembentukan watak dan diawasi oleh orang dewasa. Selain lebih mengenal alam dan lingkungan sekitar, siswa juga diberikan permainan-permainan, yel-yel yang bisa membuat siswa tertarik mengikuti alur kegiatan tersebut. Tidak hanya bermain, siswa juga diajarkan beberapa keterampilan sesuai dengan minat dan bakat yang dimiliki oleh siswa. Misalnya seperti keterampilan tali temali, semaphore, kompas, morse, sandi dan banyak keterampilan lainnya. Kegiatan Pramuka juga mampu membentuk kepribadian siswa seperti disiplin (Putra \& Hermaya, 2020).

Observasi awal yang dilakukan di beberapa sekolah juga menunjukkan bahwa banyak sekolah yang sudah aktif di kegiatan pramuka. Dengan adanya kegiatan wajib tersebut sekolah-sekolah sudah mulai membentuk dan memperbaiki sistem kerja di ekstrakurikuler kepramukaan tersebut. Mulai dari mendapatkan nomor gugusdepan, akreditasi gugusdepan, pelatihan guru untuk menjadi seorang pembina yang baik, latihan rutin setiap minggunya, dan ikut serta dalam kegiatan-kegiatan yang diadakan kwartir ranting, kwartir cabang, kwartir daerah maupun kwartir nasional.

Salah satu SDIT di Pekanbaru sangat mendukung adanya kegiatan ekstrakurikuler pramuka dan sudah mewajibkan seluruh siswa kelas $\mathrm{V}$ dan VI. Para siswa juga antusias mengikuti ektrakurikuler pramuka tersebut. Hal itu ditandai dengan para siswa yang sangat semangat mengikuti seluruh kegiatan yang dipandu oleh kakak pembina. Ekstrakurikuler pramuka dilakukan setiap hari jumat pukul 14.00 WIB. 
Dari hasil observasi awal dalam kegiatan latihan pramuka, banyak siswa yang mengikuti kegiatan tersebut. Tetapi hanya beberapa siswa saja yang serius dalam mengikuti kegiatan yang diberikan, masih ada beberapa siswa yang hanya duduk diam melihat dan mendengarkan saja. Tentu saja tidak semua siswa dengan senang hati mengikuti kegiatan pramuka, ada beberapa siswa yang terpaksa mengikuti kegiatan pramuka penggalang karena program Kurikulum 2013 yang mewajibkan kegiatan ekstrakurikuler pramuka. Siswa yang tidak memiliki minat seolah terpaksa mengikuti kegiatan pramuka yang diberikan oleh sekolah.

Kurangnya motivasi siswa menjadi salah satu kendala dalam mengikuti kegiatan pramuka penggalang. Hanya beberapa siswa yang mempunyai minat dan motivasi yang tinggi sehingga mengikuti kegiatan pramuka dengan sangat baik. Selain itu kegiatan-kegiatan yang disajikan oleh pembina pramuka juga merupakan faktor yang menentukan siswa untuk tertarik dengan kepramukaan.

Berdasarkan latar belakang diatas, maka tujuan dari penelitian ini adalah untuk mendeskripsikan bagaimana motivasi siswa dalam kegiatan pramuka SDIT di Pekanbaru dalam mengikuti kegiatan latihan pramuka penggalang.

\section{METODE PENELITIAN}

Metode yang digunakan dalam penelitian ini adalah kualitatif deskriptif. Subjek penelitian adalah siswa pramuka penggalang di salah satu SDIT di Pekanbaru. Teknik pengambilan sampel yang digunakan peneliti adalah purposive sampling. Purposive sampling menentukan subjek/objek sesuai tujuan. Dalam penelitian ini, teknik pengumpulan data yang dapat dilakukan adalah wawancara, dan dokumentasi. Wawancara merupakan interview atau kegiatan tanya jawab yang dilakukan secara bebas namun tetap terarah, dengan kata lain pertanyaanpertanyaan yang akan diajukan sudah dipersiapkan sebelumnya dan jika diperlukan pertanyaan tersebut dapat berkembang melihat situasi dan kondisi dilapangan. Wawancara dilakukan bersama pembina-pembina dan pembantu pembina yang ada di sekolah sebagai informan penelitian. Dokumentasi merupakan catatan peristiwa yang sudah berlalu bisa berbentuk tulisan, gambar, 
foto, dan karya-karya monumental dari seseorang (Sugiyono, 2015). Dalam penelitian ini, peneliti memperoleh data dari pengumpulan dokumentasi tentang kegiatan ekstrakurikuler pramuka di sekolah SDIT tersebut melalui absen kehadiran, SKU pramuka, dan foto-foto.

Sebelumnya peneliti telah melakukan observasi awal untuk mengetahui tentang gambaran sekolah, dan mengamati aktivitas belajar mengajar siswa serta bagaimana kegiatan latihan pramuka yang mereka ikuti. Kemudian peneliti melakukan wawancara awal kepada siswa untuk mengetahui bagaimana tanggapan mereka terhadap latihan pramuka yang mereka ikuti.

Wawancara awal tersebut dilakukan hanya untuk menentukan fokus penelitian dan bersifat sementara. Setelah peneliti menganalisis dari hasil wawancara awal tersebut, kemudian peneliti melakukan wawancara kedua untuk memperoleh keterangan yang lebih mendalam lagi. Selain anak, peneliti juga melakukan wawancara kepada beberapa orang narasumber di sekolah yaitu Kamabigus SDIT di Pekanbaru, KaGudep Putra dan Putri serta kakak pembina pramuka SDIT di Pekanbaru. Sebelum terjun ke lapangan peneliti sudah menyiapkan pertanyaan-pertanyaan yang dibutuhkan dalam penelitian ini. Wawancara yang dilakukan bersama siswa bersifat terbuka dan santai tetapi tidak melenceng jauh dari topik yang dibahas.

Teknik analisis data yang peneliti gunakan dalam penelitian ini menggunakan model analisiss Miles dan Huberman. Penelitian ini bersifat deskriptif maka teknik analisis data yang digunakan adalah teknik penggambaran dengan kata-kata dan kalimat yang dipisah-pisahkan menurut kategorinya untuk mendapatkan kesimpulan yang akurat.

\section{a. Analisis sebelum di lapangan}

Analisis dilakukan terhadap data hasil studi pendahuluan, atau data sekunder yaitu hasil wawancara yang akan digunakan untuk menentukan fokus penelitian. Namun fokus penelitian ini masih bersifat sementara dan akan berkembang setelah peneliti masuk dan selama di lapangan. 
b. Analisis selama di lapangan

Analisis data dalam penelitian kualitatif, dilakukan pada saat pengumpulan data berlangsung dan setelah selesai pengumpulan data dalam periode tertentu. Interactive Model (Miles dan Huberman) dalam buku Djam'an dan Aan, aktivitas analisis data terdiri atas data reduction, data display, dan conclusion drawing/verification yang dilakukan secara interaktif dan berlangsung secara terus menerus sampai tuntas, sehingga datanya mencapai jenuh.

\section{HASIL PENELITIAN DAN PEMBAHASAN}

Pramuka adalah sebuah organisasi yang menciptakan sebuah karakter anak bangsa dan merupakan suatu ekstrakurikuler wajib dalam Kurikulum 2013 pada setiap sekolah. Awalnya organisasi pramuka tidak terlalu di perdulikan oleh khalayak ramai karena dianggap organisasi yang hanya membuang-buang uang untuk demi satu perkemahan baik berbasis, daerah maupun perkemahan nasional. Tetapi karena perkembangan zaman dan organisasi pramuka telah terbukti menciptakan suatu karakter pada anak bangsa dilihat dari kode kehormatan dan kode etik sebagai pedoman yang harus dipegang pada setiap anggota pramuka dan sebagai pedoman yang harus direalisasikan pada setiap anggota. Dengan harapan siswa-siswi yang ada di Indonesia, terutama siswasiswi sekolah dasar dapat memiliki karakter yang sesuai dengan kode kehormatan dan kode etik pramuka. Maka dari itu dijadikanlah pramuka sebagai ekstrakurikuler yang wajib diikuti oleh seluruh siswa baik dari Sekolah Dasar (SD) sampai ke Sekolah Menengah Atas (SMA).

Dengan diwajibkannya pramuka di sekolah membuat kegiatan latihan pramuka menjadi lebih sulit, dikarnakan adanya paksaan yang diterima anak untuk mengikuti kegiatan pramuka. Ada siswa yang memang berniat atau suka dengan kegiatan pramuka dan ada juga yang tidak suka atau terpaksa dalam mengikuti kegiatan pramuka. Hal ini lah yang menjadi kendala dalam latihan pramuka. Dalam berlangsungnya latihan pramuka siswa-siswi yang memang menyukai pramuka akan antusias dan semangat dalam mengikuti latihan, sedangkan yang tidak suka atau terpaksa akan diam saja, atau bahkan mereka 
mengajak teman disampingnya berbicara sehingga suasana latihan menjadi lebih ricuh dan bisa mengganggu konsentrasi anak-anak lainnya yang serius mengikuti kegiatan latihan pramuka penggalang. Tidak jarang bahkan yang serius pun akan terbawa suasana dan ikut menjadi ribut, sehingga latihan pun akan terganggu dan menghabiskan waktu hanya untuk mendiamkan anak-anak yang ribut.

Tetapi bisa saja dalam pertemuan selanjutnya, anak-anak yang tadinya dirasa tidak menyukai pramuka atau terpaksa dalam mengikuti kegiatan latihan pramuka karena diwajibkan, mereka mendengarkan dan memperhatikan serta ikut dalam proses kegiatan latihan pramuka tersebut dengan baik. Dan begitu juga sebaliknya, yang dipertemuan sebelumnya memperhatikan bisa jadi tidak memperhatikan. Hal ini lah yang peniliti teliti, sebenarnya apa motivasi mereka dalam mengikuti kegiatan latihan pramuka penggalang ini. Kemudian peneliti melakukan observasi awal dan melihat sejauh mana mereka serius mengikuti kegiatan pramuka ini dari wawancara dan dokumen-dokumen seperti absen kehadiran siswa, pengisian SKU (Syarat Kecakapan Umum).

Berdasarkan hasil penelitian tentang motivasi siswa dalam mengikuti kegiatan latihan pramuka penggalang di salah satu SDIT di Pekanbaru, maka di bawah ini akan diuraikan menurut hasil data yang didapatkan selama penelitian berlangsung.

\section{Motivasi Instrinsik}

a) Kebutuhan

(1) Perasaan untuk diterima dan dihormati orang lain

Perasaan untuk diterima oleh orang lain merupakan perasaan yang timbul dalam fase perkembangan anak sekolah dasar. Dimana pada masa ini, siswa suka menjadi anggota "gank", anak pada masa ini suka membentuk kelompok tak berarah dan mereka takut sekali tidak diakui atau diabaikan. Mereka bergaul didalam gank-gank dengan corak tingkah laku dan mereka sering lupa akan waktu (Lazim \& Zulkifli).

Dari uraian tersebut maka peneliti bertanya kepada siswa "apakah benar bahwa anak mengikuti pramuka karena ingin 
diterima oleh orang lain dan tidak ingin dijauhi karena tidak ikut pramuka ?" Dari jawaban siswa, ternyata benar adanya, dimana 2 dari 12 siswa menjawab, bahwa siswa tersebut mengikuti pramuka karena ingin sama dengan temannya yang lain dan diterima di dalam lingkungan pertemanan mereka.

Terkadang anak ingin mendapatkan rasa dimana ia dihormati oleh orang lain, dalam arti anak ingin ia dianggap ada, tidak dijauhi oleh teman-temannya.

(2) Kebutuhan akan prestasi

Siswa yang ingin dihargai oleh orang lain, salah satu caranya adalah dengan mendapatkan prestasi-prestasi akademik dan non akademik, baik di sekolah maupun di luar sekolah. Ada anak yang sedari kecil sudah ditanamkan jiwa kompetisi dalam dirinya, sehingga anak tersebut selalu berusaha untuk melakukan yang terbaik dan mendapatkan penghargaan dalam suatu ajang atau kompetisi apapun. Didalam pembelajaran sekolah, bidang akademik, mendapatkan nilai tertinggi selalu dianggap menjadi tolak ukur untuk kecerdasan. Tetapi bukan hanya itu saja, non akademik juga memiliki peranan penting, karena tidak semua anak memiliki kecerdasan yang sama. Biasanya jika anak sudah pernah mendapakan kan suatu penghargaan, maka anak akan meresa ingin lagi, merasa jika ia harus bisa mendapatkan sebuah prestasi lagi dan lagi. Tidak pernah puas dengan apa yang ia dapatkan dan akan berusaha menjadi yang lebih baik lagi. Begitu juga dalam kegiatan latihan pramuka, mereka biasanya sangat antusias dalam mengikuti kegiatan latihan, selalu bertanya dalam setiap kesempatan yang ada. Selalu penasaran dan berani mencoba hal-hal baru.

(3) Kebutuhan dalam berteman

Berteman menjadi salah satu kebutuhan anak yang muncul pada fase perkembangan anak sekolah dasar. Pada masa 
perluasan hubungan sosial, anak mulai meningkat kesukaan menjalin persahabatan dengan anak-anak lain dari lingkungannya yang lebih luas dibandingkan dengan pada masa kanak-kanak awal (Lazim \& Zulkifli). Hal ini yang menjadi salah satu alasan siswa mengikuti kegiatan latihan pramuka, mengenal dan mendapatkan teman baru. "apakah adik mengikuti pramuka karena ingin mendapatkan banyak teman ?" "iya kak, kan kalo ikut pramuka jadi banyak teman, bukan yang dikelas aja, apalagi kalo ikut kemah kayak di pesantren kemaren, banyak kami kenalan sama sekolah lain (P)". Dari jawaban anak dapat disimpulkan bahwa salah satu alasan mereka mengikuti kegiatan latihan pramuka dikarekan bisa mengenal satu sama lain dan mendapatkan banyak teman.

Dalam usia ini biasanya anak sangat suka berkelompokkelompok dalam berteman. Bisa kelompok belajar atau kelompok teman karena satu lingkungan tinggal.

Latihan pramuka tidak hanya dengan teman sekelas. Latihan pramuka di Sekolah Dasar IT Pekanbaru tersebut, satu waktu bersamaan yaitu kelas IV, V dan VI. Tidak hanya itu saja, sesuai dengan program kerja kwartir ranting Tampan, yaitu kegiatan latihan gabungan pramuka penggalang se Kecamatan Tampan, menjadi kegiatan yang menarik bagi siswa, dimana siswa bisa menjalin silaturrahmi dengan anak pramuka yang ada di sekolahsekolah lain. Dari situlah ketertarikan mereka dalam latihan pramuka, bisa mengenal dan mendapatkan teman dari sekolah lain.

(4) Pujian dari orang lain

Tidak dipungkiri bahwa anak sangat senang apabila mendapatkan pujian dari orang lain, baik dalam hal belajar, berteman, bermain, prestasi akademik maupun non akademik, ataupun dalam hal penampilan. Sesuai dengan yang dijelaskan 
pada poin ke 2 dalam kebutuhan akan prestasi anak, pujian juga merupakan salah satu pemicu dalam memotivasi siswa. Pujian akan menaikkan semangat dan percaya diri seorang anak. Dari semua anak yang peneliti wawancarai, benar adanya bahwa mereka sangat senang apabila mendapatkan pujian dari orang lain. Tetapi pujian itu tidak menjadi faktor utama mereka dalam mengikuti kegiatan latihan pramuka penggalang di sekolah.

b) Harapan

(1) Ingin mendapatkan keterampilan tertentu

Ingin mendapatkan keterampilan tertentu merupakan salah satu hal yang diharapkan oleh seorang siswa. Masa sekolah dasar, disebut demikian karena umumnya mereka sedang belajar disekolah dasar dan mempelajari berbagai pengetahuan, keterampilan serta sikap dasar yang diperlukan lebih lanjut. Ada juga masa dimana anak sering menonjolkan apa yang baru diketahuinya dari sekolah dan dia bangga akan pengetahuan itu.

"Apakah adik mengikuti kegiatan pramuka karena tertarik ingin belajar keterampilan-keterampilan dalam pramuka ?" jawab "suka latihan pramuka, karena bisa belajar tentang morse, semaphore, ada juga yang belajar kompas $(\mathrm{H})$ "

"iya kak, saya jadi tau buat tandu pake stok dan tali, terus belajar morse $(\mathrm{H})$

Beberapa dari anak menjawab iya, dikarenakan rasa penasaran mengenai pelajaran yang ada dalam pramuka. Dan juga anak-anak banyak mendapatkan keterampilan tertentu yang belum mereka pelajari sebelumnya, seperti cara menggunakan kompas, membuat tandu dari stok dan tali, belajar huruf rahasia(sandi), mengenal huruf morse, bisa berkomunikasi menggunakan bendera semaphore dan lain sebagainya yang bisa mereka dapatkan ketika mengikuti kegiatan latihan pramuka.

(2) Ingin mengembangkan kemampuan tertentu 
Anak yang sudah mengetahui bakat yang ia miliki akan memiliki rasa penasaran dan ingin terus mengembangkan kemampuan yang ia miliki. Salah satu contoh yaitu tali temali, ada anak yang secara otodidak sudah bisa ikat mengikat karena kegiatan sehari-harinya, seperti mengikat tali sepatu, menyambung tali yang putus, mengikat tali pancing, dan lain sebagainya. Tetapi ketika ia mengikuti latihan pramuka ia jadi lebih tau apa itu perbedaan simpul dan ikatan, jenis-jenis tali dan macam-macam simpul dan ikatan yang ada, sehingga ia bisa mengembangkan kemampuan yang sudah ada tersebut.

(3) Memperoleh informasi dan pemahaman tertentu

Terkadang anak merasa kurang akan pengetahuan yang ia dapatkan disekolah dalam arti ketika proses belajar mengajar berlangsung. Maka dari itu anak mengikuti kegiatan ekstrakurikuler di yang ada disekolah, dimana mereka bisa memilih ekskul mana yang ingin mereka ikuti, dan salah satunya adalah pramuka. Dimana ekskul pramuka sekarang sudah diwajibkan sesuai dengan Kurikulum 2013. Di pramuka banyak pengetahuan yang tidak diajarkan dalam pembelajaran, adapan dikarnakan proses pembelajaran didalam pramuka itu belajar sambil bermain. Dan kadang mereka juga terjun langsung dalam kegiatan tersebut. Contoh seperti pada kegiatan perkemahan penggalang, mereka akan banyak belajar secara langsung dari apa yang mereka kerjakan. Seperti mencuci baju sendiri, memasak, bersih bersih tenda, cara mendirikan tenda, cara membuat dapur dan lain sebagainya. Disitu mereka akan tau juga bagaimana cara berkomunikasi dengan tetangga sebelah.

c) Minat

(1) Suka dengan kegiatan pramuka

Pada dasarnya banyak yang menyukai pramuka. Pramuka merupakan ekstrakurikuler wajib yang menyenangkan, karena 
dikemas sedemikian rupa agar tidak membosankan. Selain belajar untuk mendapatkan keterampilan kegiatan latihan pramuka juga diselingi dengan permainan-permainan yang menyenangkan untuk anak-anak.

"Apakah adik menyukai kegiatan-kegiatan yang ada dalam latihan pramuka?

Ada yang menjawab iya dan ada juga yang menjawab tidak. Anak yang menjawab iya menyukai setiap kegiatan latihan pramuka. Sedangkan anak yang menjawab tidak itu dikarenakan memang tidak ada minat untuk mengikuti kegiatan pramuka. Lokasi latihan pramuka juga berpengaruh ketika latihan pramuka. Anak lebih menyukai latihan pramuka dilakukan diluar ruang kecuali pada kondisi tertentu, seperti cuaca yang terlalu terik, hujan, dan juga asap akibat kebakaran hutan dan lahan. Latihan pramuka tidak selalu berada di luar ruangan atau lapangan, latihan juga dilakukan di dalam ruangan ketika dibutuhkan, seperti beberapa keterampilan yang membutuhkan papan tulis yaitu morse, sandi, dan lain sebagainya. Anak laki-laki lebih menyukai latihan yang berada diluar ruangan (lapangan). Sedangkan anak perempuan mereka suka latihan didalam dan diluar ruangan. Peneliti juga bertanya "kegiatan apa saja yang disukai anak dalam latihan pramuka ?" Rata-rata kegiatan latihan yang disukai anak-anak adalah latihan semaphore, sandi, morse, dan kegiatan berkemah.

(2) Suka bersosialisasi

Ada anak-anak yang tidak suka dengan keramaian dan ada pula anak suka dengan keramaian. Maka dari itu ada anak yang suka bersosialisasi dengan lingkungan sekitarnya. Ekskul pramuka juga merukan tempat dimana anak dapat bersosialisasi dengan teman sebaya satu kelas, satu sekolah atau bahkan dengan teman sebaya sekolah lainnya. Bahkan anak juga bisa 
bersosialisasi dengan yang lebih dewasa usianya, seperti kakakkakak pembina atau pun kakak-kakak kelas yang juga ikut kegiatan pramuka.

\section{Motivasi ekstrinsik}

a) Keluarga

(1) Latar belakang keluarga anggota pramuka

Keluarga memiliki peranan yang sangat penting dalam mengembangkan pribadi anak. Latar belakang keluarga menjadi salah satu motivasi yang bisa memicu anak dalam mengikuti kegiatan pramuka. Keluarga memberikan pengaruh yang besar terhadap seluruh anggotanya, sebab selalu terjadi interaksi yang paling bermakna, paling berkenan dengan nilai yang sangat mendasar dan intim (Djawad Dahlan dalam Landasan bimbingan dan konseling, 2012). Dimana keluarga merupakan tempat pembelajaran pertama anak, maka ia akan melihat bagaimana cara keluarga nya melakukan kegiatan sehari hari.

Adapun keluarga yang memiliki latar belakang seorang pramuka bisa jadi menurun ke anak, karena anak meniru apa yang dilakukan oleh ayah dan ibunya. Tetapi ada juga yang tidak memiliki latar belakang pramuka sama sekali tetapi tetap mengikuti dan menyukai kegiatan pramuka. Bisa itu adalah faktor lain seperti lingkungan atau pun media massa yang menimbulkan anak tertarik untuk mengikuti kegiatan pramuka tersebut.

(2) Adanya paksaan dari keluarga

Anak-anak yang benar-benar menyukai pramuka akan senang ketika adanya latihan pramuka, mereka bisa belajar sambil bermain. Dan kebanyakan dari anak-anak tersebut secara suka rela dari keinginan hati mengikuti kegiatan pramuka.

Namun ada juga yang terpaksa dalam mengikuti kegiatan pramuka, dikarenakan keinginan dari orang tua yang sudah 
memiliki keturuanan atau gelar keluarga pramuka dari dulunya. Bisa jadi walaupun tidak dari keluarga pramuka anak dipaksa untuk mengikuti kegiatan pramuka dikarnakan keinginan orang tua dimana dulu adalah keinginan orang tua yang tidak tercapai dan di paksakan ke anaknya.

(3) Adanya motivasi dari keluarga inti

Adapun keluarga selalu mendukung segala kegiatan positif yang dilakukan anak. Dari data (Ririn Oktavianis : 2018 ) diartikan bahwa peran orang tua sangat memberikan masukan yang berarti pada siswa untuk mengikuti kegiatan ektrakurikuler pramuka. Faktor keluarga merupakan salah satu dukungan yang dapat memotivasi siswa secara ekstrinsik dalam mengikuti segala sesuatu kegiatan dalam hal ini kegiatan ektrakurikuler pramuka.

(4) Adanya motivasi dari keluarga jauh (kakek, nenek, paman, bibi, sepupu, dll)

Keluarga besar juga memberikan pengaruh terhadap anak, walaupun tidak sebesar keluarga inti.

b) Lingkungan

(1) Sebab ajakan dari teman

Lingkungan juga merupakan salah satu faktor yang dapat mempengaruhi motivasi siswa dalam mengikuti kegiatan latihan pramuka. Ada beberapa alasan, dan salah satu alasannya adalah ajakan dari teman sebaya atau sepermainan. Anak-anak yang kurang motivasi dari dalam diri mendapat dorongan dari teman agar mengikuti kegiatan latihan pramuka bersama-sama.

(2) Pernah ada kegiatan pramuka didekat rumah

Biasanya anak tertarik mengikuti suatu kegiatan pasti ada sebabnya, dan bisa jadi salah satu penyebab anak mengikuti kegiatan pramuka dikarenakan pernah melihat kegiatan pramuka 
itu sendiri. Seperti latihan pramuka ataupun kegiatan perkemahan didekat tempat tinggal anak tersebut.

(3) Adanya pengelompokkan dalam berteman

Seperti yang telah dijelaskan pada poin satu (1), adanya kelompok-kelompok dalam berteman berpengaruh terhadap motivasi siswa dalam mengikuti latihan. Apabila siswa tidak ikut maka, siswa tersebut merasa sendiri tidak memiliki teman. Karena anak pada usia ini masih cenderung berkelompokkelompok dalam berteman.

(4) Adanya motivasi dari sekolah

Lingkungan merupakan salah satu faktor ekstrinsik dalam memotivasi siswa. Lingkungan disini termasuk didalamnya adalah lokasi atau jarak kesekolah tidak terlalu jauh serta temanteman siswa yang ikut serta dalam kegiatan ekstrakurikuler pramuka. Siswa cenderung senang jika didalam suatu kegiatan tersebut banyak teman yang mengikutinya.

c) Imbalan

Adanya nilai tambahan bagi anak yang ikut pramuka dan juga penghargaan yang anak dapatkan ketika mengikuti kegiatan perlombaan dalam perkemahan yang diadakan oleh Gugusdepan, kwaran, ataupun kwarda. Anak-anak yang berprestasi atau memenangkan lomba mendapatkan hadiah berupa piala dan piagam penghargaan. Adapun anak-anak yang tidak mendapatkan juara juga diberi penghargaan oleh panitia karena telah ikut serta dan aktif selama kegiatan perkemahan berlangsung yaitu berupa sertifikat.

Sekolah juga memberikan penghargaan kepada anak-anak pramuka yang telah membawa nama sekolah dan menang perlombaan dalam suatu kegiatan perkemahan penggalang. Biasanya sekolah akan memberikan apresiasi kepada anak pramuka pada acara penyerahan piala yang mereka dapatkan ketika berlomba untuk diserahkan kepada sekolah dan kemudian sekolah 
juga akan memberikan alat tulis seperti buku, pena, pencil maupun uang saku sebagai bentuk penghargaan atas prestasi yang telah mereka peroleh.

Imabalan atau reward merupakan salah satu hal yang dapat meningkatkan motivasi anak dalam prestasi.

Reward dan punishment sangat penting dalam memotivasi siswa, karena melalui reward dan punishment siswa akan menjadi lebih percaya diri dan bertanggungjawab dengan tugas yang diberikan. Reward dan punishment adalah dua kata yang saling bertolak belakang, akan tetapi kedua hal tersebut saling berkaitan, keduanya memacu siswa untuk meningkatkan kualitas kerja (International jurnal of elementary education). Reward dan punishment sangat erat kaitannya dengan pemberian motivasi siswa (Febrianti : 2014).

\section{SIMPULAN DAN REKOMENDASI}

Motivasi siswa dalam mengikuti kegiatan latihan pramuka penggalang di salah satu SDIT di Pekanbaru terbagi ke dalam 2, yaitu motivasi instrinsik dan ekstrinsik. Faktor yang mempengaruhi motivasi instrinsik siswa terdiri dari (1) Kebutuhan, dalam hal ini motivasi yang ada datang dari dalam diri siswa guna memenuhi kebutuhan yang ada dalam diri siswa seperti kebutuhan akan prestasi atau pun kebutuhan dalam berteman (2) harapan, salah satu faktor yang mendorong siswa untuk ikut aktif dalam kegiatan pramuka dimana siswa dapat mengembangkan kemampuan tertentu yang dimiliki siswa maupun yang ingin dipelajari oleh siswa, dan (3) minat, faktor karena adanya rasa suka atau keinginan untuk mengikuti kegiatan latihan pramuka tanpa ada paksaan oleh orang lain. Sedangkan motivasi ekstrinsik di pengaruhi oleh faktor (1) keluarga, karena adanya latar belakang keluarga yang anggota pramuka, (2) lingkungan, lingkungan berteman siswa menjadi salah satu dorongan siswa untuk ikut dalam kegiatan pramuka , (3) imbalan, imbalan ini juga merupakan sedikit dari salah satu sebab anak ikut dalam kegiatan pramuka, karena adanya penghargaan yang 
diberikan oleh pihak sekolah kepada siswa yang berprestasi dalam kegiatan pramuka, menjadi pemicu munculnya motivasi siswa tersebut.

Berdasarkan simpulan yang ada, maka peneliti memberikan rekomendasi sebagai berikut:

1. Untuk sekolah agar dapat memisahkan atau membedakan latihan pramuka yang umum dan khusus(yaitu siswa yang benar-benar menyukai dan ingin mengikuti kegiatan pramuka).

2. Untuk guru dan pembina pramuka, hendaknya dapat terus memotivasi siswa dalam mengikuti kegiatan latihan pramuka, dan memberikan latihan yang menarik agar siswa lebih terdorong untuk mengikuti dan bersemangat dalam kegiatan latihan pramuka.

3. Untuk siswa, berdasarkan penelitian ini diharapkan agar siswa lebih bersemangat dan bersungguh-sungguh dalam mengikuti kegitaan latihan pramuka guna mendapatkan hasil yang memuaskan dan bermanfaat dalam kehidupan siswa tersebut.

\section{DAFTAR PUSTAKA}

Buku panduan kursus pembina pramuka mahir tingkat dasar. (2017). Kwartir cabang gerakan pramuka Kota Pekanbaru.

Departemen Pendidikan dan Kebudayaan. (2014). Kegiatan ekstrakurikuler pada pendidikan dasar dan pendidikan menengah. Jakarta. Depdikbud.

Dimyati \& Mudjiono. (2006). Belajar dan pembelajaran. Rineka Cipta. Jakarta

Hamalik, O. (2013). Kurikulum dan pembelajaran. Bumi Aksara. Jakarta

Handrianto, P. (2012). Faktor-faktor yang berpengaruh terhadap motivasi belajar. (Online), http://sainsjournalfst-11.web.unair.ac.id (diakses 09 Februari 2020).

Husamah, dkk. (2016). Belajar \& pembelajaran. UMM. Malang.

Lazim. N \& Zulkifli. (2014). Perkembangan belajar peserta didik. FKIP Universitas Riau. Pekanbaru.

Lisayanti, D. (2014). Implementasi kegiatan pramuka sebagai ekstrakurikuler wajib berdasarkan kurikulum 2013 dalam upaya pembinaan karakter. Journal of educational social studies. Universitas Negeri Semarang.

Martono. (2012). Sosiologi perubahan sosial: Perspektif klasik, modern, posmodern, dan poskolonial. Raja Grafindo Persada. Jakarta.

Oktavianis, Ririn, et al. (2018). Analisis faktor-faktor motivasi siswa dalam mengikuti kegiatan ekstrakurikuler pramuka di SD Negeri 034 Taraibangun. 
[Jurnal online] Diakses dari https://jom.unri.ac.id/index.php/JOMFKIP/article/view/17180 Pekanbaru.

Putra, M. J. A., \& Hermaya, V. (2020). Primary School Students' Discipline through Scouting. Journal of Teaching and Learning in Elementary Education, 3(1), $69-76$.

Putra, N. (2012). Metode penelitian kualitatif pendidikan. Rajawali Pers. Jakarta.

Sardiman, A.M. (2011). Interaksi \& motivasi belajar mengajar. PT. Raja Grafindo Persada. Jakarta.

Satori, D. \& Aan. (2014). Metodologi penelitian kualitatif. Alfabeta, cv. Cetakan ke 6. Bandung.

Sugiyono. (2013). Metode penelitian pendidikan: Pendekatan kuantitatif, kualitatif, dan R\&D. Alfabeta. Bandung.

Sumarsih, E. dkk. (2013). Aktivitas pramuka untuk penggalang ramu. Erlangga. Jakarta.

Sunardi, B. \& Andri. Boyman. (2001). Ragam latih pramuka. Nuansa Muda, cetakan pertama.

Takijoeddin, M. (2008). Panduan bagi pembina pasukan. Pustaka Tunasmedia. Jakarta. 